\title{
Variation in Bentgrass Susceptibility to Typhula incarnata and in Isolate Aggressiveness Under Controlled Environment Conditions
}

\author{
S. W. Chang, Department of Plant, Soil and Insect Sciences, University of Massachusetts, Amherst 01003; \\ T. H. Chang, Department of Plant Resources, College of Life Science and Natural Resources, Sangju National Uni- \\ versity, Sangju-city, Gyeongsang Buk-Do, 742-711, South Korea; R. A. B. Abler, Biological Sciences, University of \\ Wisconsin-Manitowoc, Manitowoc 54220; and G. Jung, Department of Plant, Soil and Insect Sciences, University \\ of Massachusetts, Amherst 01003
}

\begin{abstract}
Chang, S. W., Chang, T. H., Abler, R. A. B., and Jung, G. 2007. Variation in bentgrass susceptibility to Typhula incarnata and in isolate aggressiveness under controlled environment conditions. Plant Dis. 91:446-452.

Typhula incarnata, the causal agent of gray snow mold, is an important winter pathogen of turfgrasses in the northern United States. The relative susceptibility of cultivars of three bentgrass species (creeping, colonial, and velvet bentgrass) to Typhula incarnata and the aggressiveness of $15 \mathrm{~T}$. incarnata isolates obtained from infected turfgrasses on golf courses in Michigan, Minnesota, and Wisconsin were evaluated under controlled conditions. A hypersensitive type of resistance response to $T$. incarnata was not observed in any cultivar. Disease severity increased with higher inoculum concentration of $T$. incarnata. Colonization by gray snow mold gradually decreased with increasing plant age from 11 weeks after seeding in most cultivars tested, suggesting that age-related resistance was expressed over time. There were significant differences in disease severity among the three bentgrass species, particularly between tetraploid (creeping and colonial) and diploid (velvet) species, and among cultivars within each species, indicating varying levels of susceptibility to T. incarnata. All 15 isolates were pathogenic on bentgrass and were significantly different in aggressiveness, but aggressiveness was not related to geographic origin. Therefore, turfgrass breeders should be able to use one or a few virulent representative isolates of the pathogen to screen for resistance.
\end{abstract}

Additional keywords: Agrostis, snow mold, Typhula blight

Bentgrass is the most widely used turfgrass species on golf course putting greens and fairways throughout the United States. Five bentgrass species are commonly used for turfgrass in the United States: creeping (Agrostis stolonifera L.), colonial (A. capillaries L.), velvet (A. canina L.), redtop (A. gigantean L.), and dryland (A. castellana L.). Among those species, creeping, colonial, and velvet bentgrasses are the most popular species used for high-quality tees and greens of golf courses $(2,27,35)$.

Typhula incarnata Lasch ex Fr., the causal agent of gray snow mold, is an important winter pathogen of turfgrass in the northern United States $(9,16,30)$. Symptoms of gray snow mold on turfgrass usually appear as circular, water-soaked, or straw-colored patches after snow melt in late winter or early spring (32). Plants in diseased patches may be matted, slimy, and covered with gray mycelium of the

Corresponding author: G. Jung

E-mail: jung@psis.umass.edu

Accepted for publication 23 October 2006.

doi:10.1094/PDIS-91-4-0446

(C) 2007 The American Phytopathological Society pathogen (18). During the spring thaw, gray snow mold produces numerous yellow or reddish-brown sclerotia which may persist through the summer and early fall as resting structures. Later, they become the primary inoculum source when weather conditions during winter become more favorable $(16,24)$.

At most golf courses, disease control generally relies on fungicide applications supplemented by cultural approaches, such as fertilization and snow removal (32). However, fungicides are expensive, time consuming to apply, and may have potential negative environmental impacts $(6,16)$. In addition, fungicide applications may have limited efficacy due to long snow cover during winter. For these reasons, the planting of resistant cultivars would be an economical and effective method of controlling gray snow mold $(6,36)$.

In the United States, however, there is no report of commercial bentgrass cultivars that are highly resistant to the gray snow mold pathogen $(1,5)$. Gould et al. (15) reported that four common bentgrass species (creeping, colonial, velvet, and redtop) were susceptible to gray snow mold. Considerable differences in susceptibility to $T$. incarnata among cultivars within species also were reported by Årsvoll (1) and Vargas (32).
T. incarnata possesses wide genetic and ecological diversity $(5,9,24,33)$. Matsumoto and Tajimi (24) reported that $T$. incarnata populations had many different vegetative compatibility groups. Bruehl and Machtmes (5) suggested that there may be at least 39 alleles at the two incompatibility loci, A and B, in a sample of 32 field dikaryons. Chang et al. (9) also reported that $T$. incarnata isolates collected from Wisconsin, Michigan, Minnesota, and Utah have adaptability to diverse environmental conditions compared with $T$. ishikariensis and $T$. phacorriza because they were collected from every site sampled in those states. Vergara et al. (33), using molecular data obtained from random amplified polymorphic DNA (RAPD) analysis, suggested that high outcrossing and sexual recombination of $T$. incarnata may be key factors explaining a high level of genetic variation among isolates of $T$. incarnata.

Genetic diversity might explain the variation in aggressiveness of $T$. incarnata $(24,28)$. Variation in aggressiveness of $T$. incarnata can play a critical role in the success of disease management strategies, including resistance screening of cultivars to gray snow mold $(6,34)$. Previously completed resistance screenings of turfgrass to snow mold pathogens were accomplished mostly in field trials (29). However, snow mold development under field conditions can be erratic due to the inconsistency of weather conditions from year to year, because disease development requires unique weather conditions $(4,9,17,29,30)$. Therefore, cultivar evaluations under controlled conditions, such as in growth chambers, can help to ensure adequate infection levels, to improve efficiency in terms of time, and to predict a field result $(7,8,25,34)$, although the method has a limitation, in that field evaluation under various environmental factors is needed. Nonetheless, there is no information available on relative susceptibility of commercial bentgrass cultivars and on variation in aggressiveness of various isolates of $T$. incarnata under controlled conditions.

In the present study, therefore, we examined the effect of inoculum concentration and plant age on infection of bentgrass plants in controlled conditions. The relative susceptibility of nine cultivars repre- 
senting three bentgrass species (creeping, colonial, and velvet) to T. incarnata also was evaluated under these conditions. The variability in aggressiveness of 15 isolates of $T$. incarnata collected from different geographic areas (Wisconsin, Minnesota, and Michigan) on creeping bentgrass cultivars was examined.

\section{MATERIALS AND METHODS}

Plant materials. Four creeping bentgrass cultivars (L-93, Penncross, Pennlinks, and Providence), three colonial bentgrass cultivars (Bardot, SR 7100, and Tiger), and three velvet bentgrass cultivars (Barvaria, Greenwich, and Vesper) were examined in this study. Cultivars of creeping and colonial bentgrass $(0.056 \mathrm{~g}$ of seed), and velvet cultivars (0.035 $\mathrm{g}$ of seed) were sown evenly in plastic pots (5.3 by 5.3 by $5.1 \mathrm{~cm}$ ) filled with potting soil (Metro Mix 366-P; Scott's Company, Marysville, $\mathrm{OH}$ ). The plants were grown in the greenhouse at 18 to $28^{\circ} \mathrm{C}$ with $16 \mathrm{~h}$ of light per day. The plants were mowed weekly with a scissors at a height of 0.6 $\mathrm{cm}$ from 2 weeks after germination until they were transferred to a controlled environment chamber after randomization. The chamber was set at $10^{\circ} \mathrm{C}$ and 10 -h day length for 7 days, $5^{\circ} \mathrm{C}$ and 8-h day length for 7 days, and $2^{\circ} \mathrm{C}$ and 6-h day length for 7 days to simulate fall weather conditions before snow cover in nature. This process, called hardening, is very important before inoculation because low temperature and short day length are required for development of snow mold resistance within the plants (1,12). Water-soluble fertilizer (0.02-0.005-0.02 g of N-P-K per pot; SunGrow Company, Austin, TX) was applied biweekly from 4 weeks after germination until 2 weeks before hardening. Plants to be inoculated were placed into plastic trays containing distilled water to assure constant moisture.

Fungal isolates and inoculum preparation. Twenty isolates of $T$. incarnata were selected randomly from previously identified collections which were maintained on potato dextrose agar (PDA; Difco Laboratories, Detroit) at $4 \pm 1^{\circ} \mathrm{C}$ in the dark (9) (Table 1, Fig. 1). Inoculum preparation followed the same procedures described by Chang et al. (7). In brief, mycelium suspensions were produced by taking five culture plugs $(5 \mathrm{~mm}$ in diameter) from the actively growing colony edge and transferring them to $20 \mathrm{ml}$ of potato dextrose broth (PDB; Difco Laboratories) in 250-ml flasks. Broth cultures were grown at $10 \pm 1^{\circ} \mathrm{C}$ in the dark. After 20 days, mycelium was harvested from four to six flasks, mixed together, and air dried for 30 min under a laminar flow hood. Residual water in air-dried mycelia finally was removed by vacuum filtration for $3 \mathrm{~min}$ under a pressure of $21 \mathrm{psi}\left(1.5 \mathrm{~kg} / \mathrm{cm}^{2}\right)$ through cheesecloth, and mycelium weights were recorded. Mycelium then was homogenized in a blender with $20 \mathrm{ml}$ of sterile, distilled water for $30 \mathrm{~s}$. These suspensions were adjusted with sterile, distilled water to desired concentrations according to experiments described below and used immediately for inoculation.

Inoculation procedure. Sterile pipettes were used to deliver $1 \mathrm{ml}$ of inoculum solution directly on the soil line in the center of each pot. Following inoculation, the plants were arranged in a randomized complete block design and kept in a plastic container ( 70 by 40 by $15 \mathrm{~cm}$; Rubbermaid, Wooster, $\mathrm{OH}$ ) in which approximately $30 \%$ of the volume was filled with wetted potting soil (1:1 soil:distilled water in volume). Moisture was applied by evenly spraying the plants with distilled water with a hand sprayer until runoff from leaves was observed, and the plastic box was covered with a lid to maintain humidity required for disease development. The box was transferred to a controlled envi- ronment chamber set at $2^{\circ} \mathrm{C}$ in darkness for 21 days, $5^{\circ} \mathrm{C}$ and 6 -h day length for 7 days, and $10^{\circ} \mathrm{C}$ and 8 -h day length for 10 days. Immediately after inoculation, the pots in the plastic container were returned to plastic trays containing water to assure constant moisture.

Effect of inoculum concentration and plant age on disease development. To evaluate the effect of inoculum concentration on disease development on 11-weekold plants, mycelial suspensions of $T$. incarnata isolates 11 and 19 were adjusted to $0.1,0.2,0.3$, and $0.4 \mathrm{~g} / \mathrm{ml}$ mycelium fresh weight $(\mathrm{mfw})$ with sterile, distilled water. Six bentgrass cultivars-L-93, Penncross, Pennlinks, and Providence (creeping); Tiger (colonial); and Greenwich (velvet)-were inoculated with each inoculum concentration. Additionally, in order to evaluate the effect of plant age on disease development, 9-, 11-, 13-, and 15week-old plants of the same cultivars were

Table 1. List of Typhula incarnata isolates used in this study

\begin{tabular}{llllc}
\hline No. & \multicolumn{1}{c}{ Code } & \multicolumn{1}{c}{ Source } & $\begin{array}{c}\text { Geographic origin } \\
\text { (city, state) }\end{array}$ & $\begin{array}{c}\text { Year } \\
\text { collected }\end{array}$ \\
\hline 1 & GLAD 4.1 & Gladstone Golf Course & Gladstone, MI & 2002 \\
2 & IR 9.2 & Indian River Golf Course & Indian river, MI & 2002 \\
3 & IR 15.3 & Indian River Golf Course & Indian river, MI & 2002 \\
4 & LONG 9.4 & Lakewood Blackshire Golf Course & Oscoda, MI & 2002 \\
5 & NEW 17.3 & Newberry Country Club & Newberry, MI & 2002 \\
6 & RFR 5.3 & Red Fox Run Golf Course & Gwinn, MI & 2002 \\
7 & CW 18.3 & Crosswoods Golf Course & Crosslake, MN & 2002 \\
8 & LP 2. 1 & Long Prairie Golf Course & Long Prairie, MN & 2002 \\
9 & OC 11. & Oak Crest Golf Course & Roseau, MN & 2002 \\
10 & SN 9 & Superior National Golf Course & Lutsen, MN & 2002 \\
11 & NE 108.8.3 & Vernon Hills Golf Course & Peshtigo, WI & 2001 \\
12 & NE 110.1.5 & Wander Springs Golf Course & Greenleaf, WI & 2001 \\
13 & NW 4.2.1 & Ashland Elks Golf Course & Ashland, WI & 2001 \\
14 & NW 43.2.5 & Madeline Island Golf Course & La Pointe, WI & 2001 \\
15 & NW 88.9.2 & Whitetail Golf Course & Colfax, WI & 2001 \\
16 & SE 57.3.5 & Lauderdale Lakes Country Club & Elkhorn, WI & 2001 \\
17 & SE 90.6.3 & Shoop Park Golf Course & Racine, WI & 2001 \\
18 & SW 2. 6.5 & Baraboo Golf Course & Baraboo, WI & 2001 \\
19 & SW 5.4.5 & Blackhawk Golf Course & Janesville, WI & 2001 \\
20 & SW 74.10.4 & Sun Prairie Golf Course & Sun Prairie, WI & 2001 \\
\hline
\end{tabular}

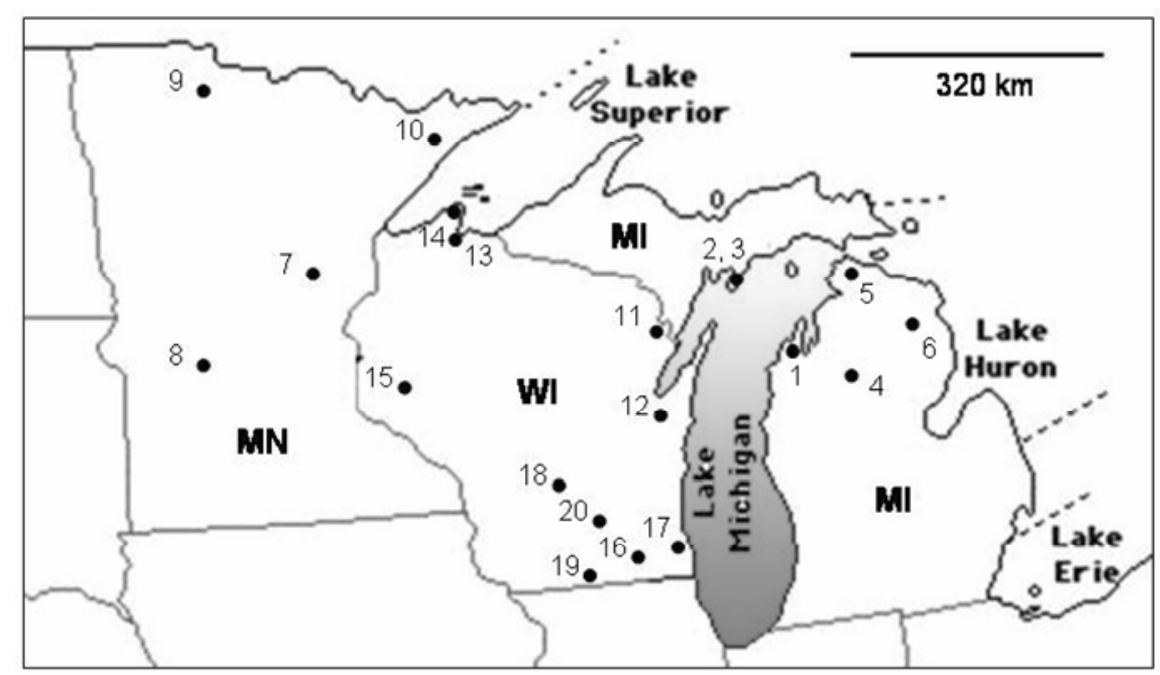

Fig. 1. Sampling sites of Michigan (MI), Minnesota (MN), and Wisconsin (WI). Solid circles with the numbers on the map indicate sampling locations, golf courses listed in Table 1. 
inoculated with a mycelial suspension (0.3 $\mathrm{g} / \mathrm{ml} \mathrm{mfw}$ ) of $T$. incarnata isolates 11,13 , and 19.

Evaluation of the susceptibility of bentgrass cultivars. To evaluate the susceptibility of different bentgrass cultivars to gray snow mold, inoculum $(0.3 \mathrm{~g} / \mathrm{ml}$ $\mathrm{mfw}$ ) of each of five isolates (nos. 11, 12, 13, 16, and 19) was prepared separately and applied independently on 15-week-old plants of nine cultivars (L-93, Penncross, Providence, Bardot, SR 7100, Tiger, Barvaria, Greenwich, and Vesper).

Evaluation of the aggressiveness of $\boldsymbol{T}$. incarnata isolates. To evaluate the aggressiveness of isolates of $T$. incarnata from different geographic regions, inoculum $(0.3 \mathrm{~g} / \mathrm{ml} \mathrm{mfw})$ from 15 isolates collected from three different states (Michigan: nos.
1, 2, 3, 4, 5, and 6; Minnesota: nos. 7, 8, 9, and 10; and Wisconsin: nos. 14, 15, 17, 18, and 20) was applied on 15-week-old plants of two creeping bentgrass cultivars (L-93 and Providence).

Disease evaluation and statistical analysis. Disease severity was assessed by visual determination of percentage of area colonized and infected by mycelia at 21 , 28 , and 38 days after inoculation. All three experiments described above were conducted twice in a factorial design with three replicates. Data were analyzed using mean values of two runs in each experiment because no significance was detected between the runs.

All statistical analyses were conducted using the general linear models procedure (PROC GLM) in SAS (version 6.12; SAS
Institute Inc., Cary, NC). Differences among plant ages, cultivars, and isolates were compared using Fisher's protected least significant differences (LSD) test at $P$ $=0.05$. Analysis of variance (ANOVA) was used to evaluate the effects of plant age on disease development and the disease severity of two creeping bentgrass cultivars by 15 isolates of $T$. incarnata with different geographic origin. Disease severity on the inoculum concentration of T. incarnata isolates 11 and 19 was determined using linear regression of the Sigmaplot program (version 5.0; SPSS Inc., San Rafael, CA).

For disease severity for nine cultivars of three bentgrass species to five isolates of $T$. incarnata, the source of variation for bentgrass species was partitioned into two

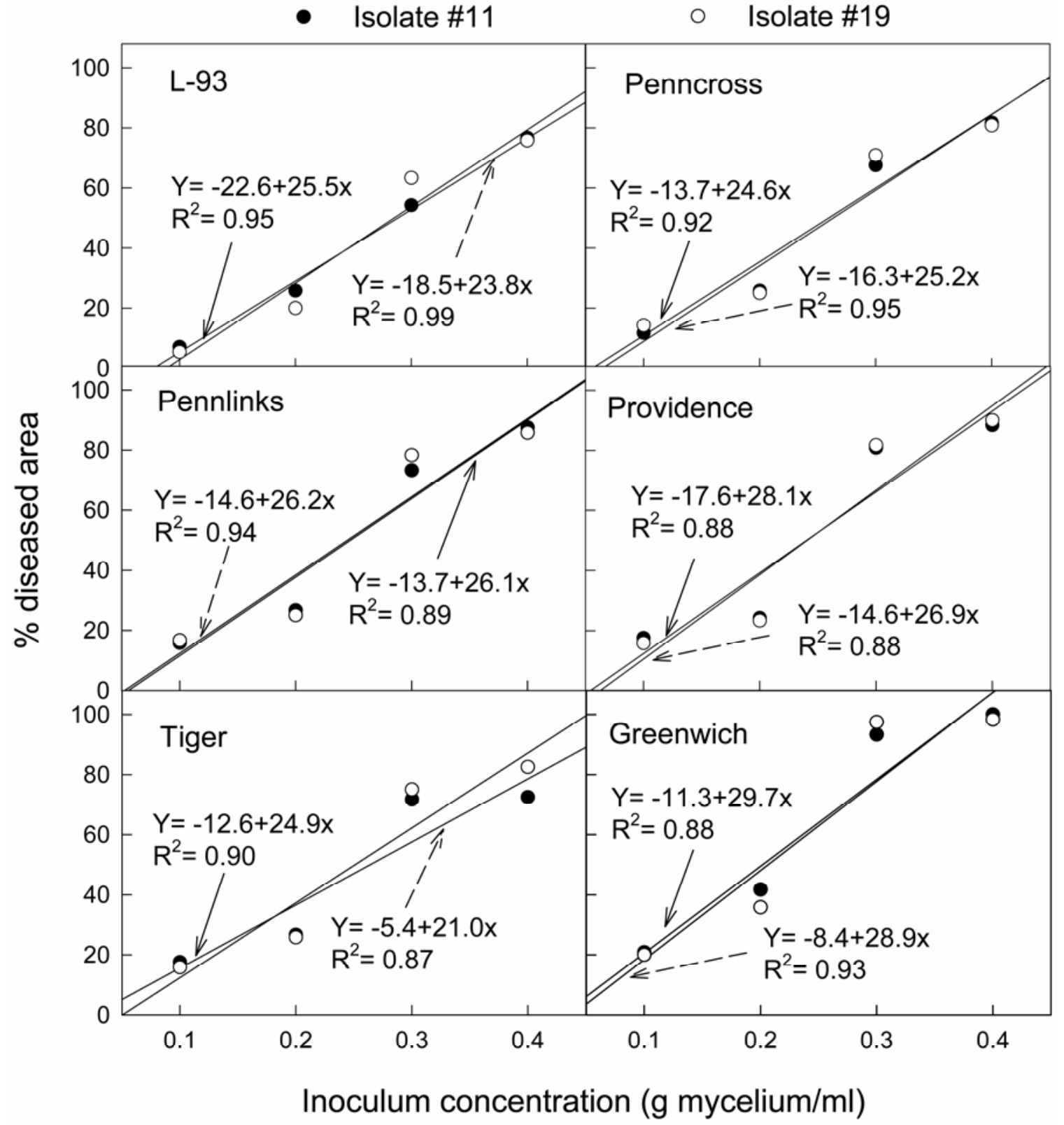

Fig. 2. Effect of inoculum concentration on disease development in six cultivars of three bentgrass species (creeping: L-93, Penncross, Pennlinks, and Providence; colonial: Tiger; and velvet: Greenwich) inoculated by one of two isolates of Typhula incarnata with four inoculum concentrations in the growth chamber. Short dash and solid arrows within each box indicate regression lines and equations of isolates 11 and 19 , respectively. 
orthogonal contrasts: velvet $\left(\mathrm{A}_{1} \mathrm{~A}_{1}\right)$ bentgrass versus creeping $\left(\mathrm{A}_{2} \mathrm{~A}_{2} \mathrm{~A}_{3} \mathrm{~A}_{3}\right)$, and colonial $\left(\mathrm{A}_{1} \mathrm{~A}_{1} \mathrm{~A}_{2} \mathrm{~A}_{2}\right)$ bentgrasses, and creeping versus colonial bentgrass. The velvet bentgrass versus creeping and colonial bentgrass contrast was performed in order to test for differences between bentgrass species having diploid or tetraploid

Table 2. Analysis of variance for gray snow mold severity on four cultivars (L-93, Penncross, Pennlinks, and Providence) of creeping bentgrass inoculated with three isolates of Typhula incarnata at four plant ages (9-, 11-, 13-, and 15-week-old plants from germination to inoculation) in the growth chamber

\begin{tabular}{lrccc}
\hline Source of variation & df & Mean square & $\boldsymbol{F}$ value & \multicolumn{1}{c}{$\boldsymbol{P}$} \\
\hline Replication & 4 & 75.2 & 0.94 & 0.4403 \\
Cultivar & 3 & $1,785.0$ & 22.36 & $<0.0001$ \\
Plant age (cultivar) & 12 & $6,391.8$ & 80.05 & $<0.0001$ \\
Isolate & 2 & 238.8 & 2.99 & 0.0522 \\
Isolate $\times$ cultivar & 6 & 139.1 & 1.74 & 0.1120 \\
Isolate $\times$ plant age (cultivar) & 24 & 470.1 & 5.89 & $<0.0001$ \\
Error & 235 & 79.8 & $\ldots$ & $\ldots$ \\
\hline
\end{tabular}

genomes. Similarly, the creeping versus colonial bentgrass contrast served to test for differences between bentgrass species having different tetraploid genomes. This method also was used to partition the interactions of the bentgrass species with $T$. incarnata isolates. All treatments were assumed to be fixed and blocks were assumed to be random in all ANOVAs (SAS 6.12: SAS Institute Inc.). Contrasts were computed according to the procedures of Steel et al. (31).

\section{RESULTS}

Disease severity significantly increased within cultivars as inoculum concentration increased from 0.1 to $0.4 \mathrm{~g} / \mathrm{ml} \mathrm{mfw}$ (Fig.

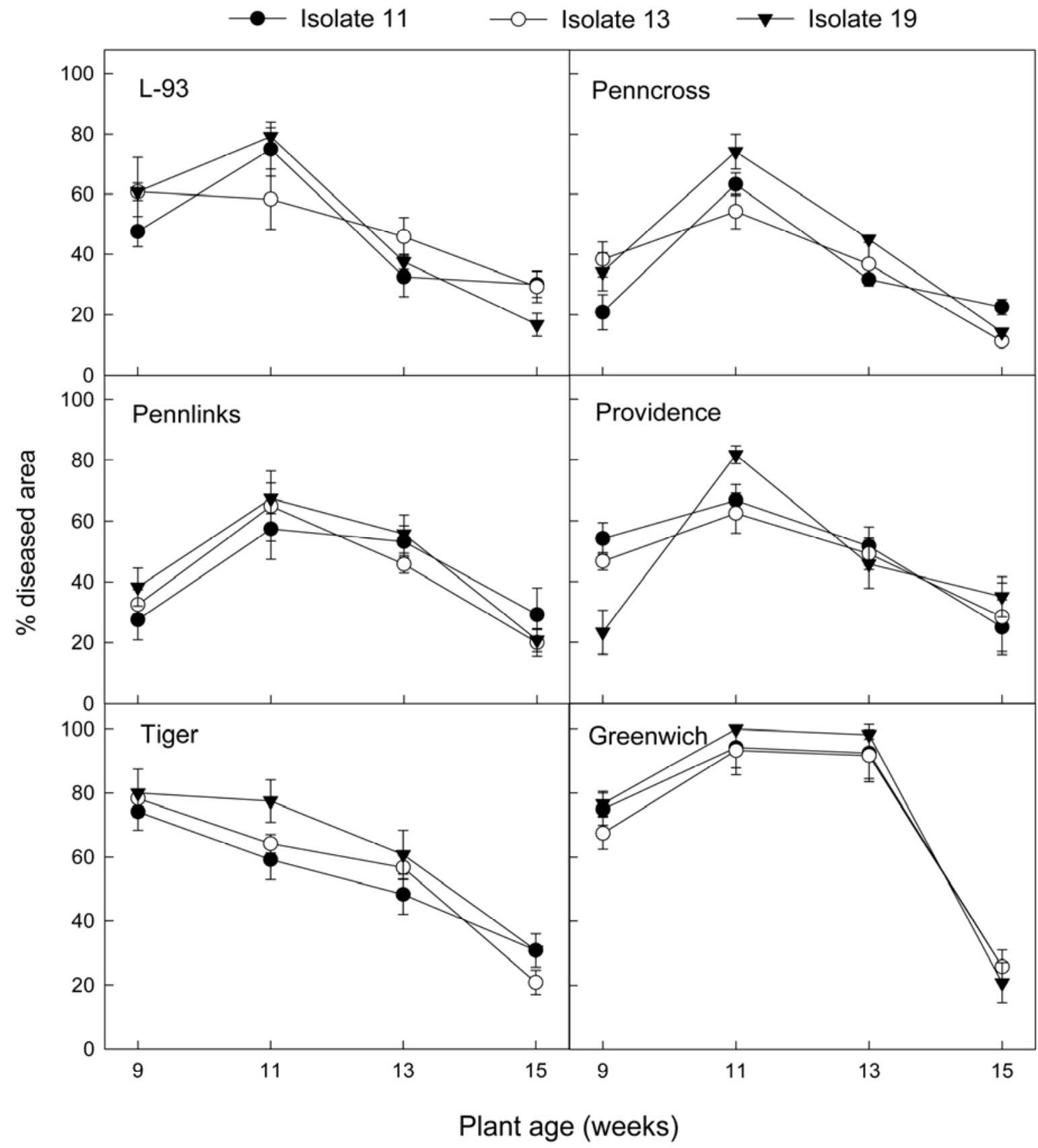

Fig. 3. Disease severity of six cultivars of three bentgrass species (creeping: L-93, Penncross, Pennlinks, and Providence; colonial: Tiger; and velvet: Greenwich) inoculated with each of three isolates of Typhula incarnata at four plant ages (9-, 11-, 13-, and 15-week-old plants from germination to inoculation) in the growth chamber. Disease severity was based on percent area diseased. Bars represent standard error of the mean. 
2). A linear relationship was found between inoculum concentration and disease severity in all six bentgrass cultivars. Mycelial concentration used for the inoculation of the cultivars explained a minimum of $88 \%$ of the variation in disease severity. Typical gray snow mold symptoms with circular and water-soaked patches were induced on the plants inoculated with 0.1 $\mathrm{g} / \mathrm{ml} \mathrm{mfw}$. At $0.4 \mathrm{~g} / \mathrm{ml} \mathrm{mfw}$, the four creeping bentgrass cultivars were severely infected (more than $76 \%$ diseased areas), as were cultivars of velvet and colonial bentgrass (Fig. 2). Significant effects $(P<$ 0.0001 ) on disease severity for cultivar and inoculum concentration within cultivar were detected, but no interactions between isolate and cultivar. Generally, disease severity was significantly less on L-93 at most inoculum concentrations than on other cultivars of creeping bentgrass. However, velvet bentgrass cv. Greenwich had much greater disease severity than cultivars of creeping and colonial bentgrasses (Fig. 2).

The ANOVA analysis showed highly significant effects of cultivar, plant age (cultivar), and isolate $\times$ plant age (cultivar) on disease severity of four creeping bentgrass cultivars (Table 2). Disease severity of all creeping bentgrass cultivars, as well as the velvet bentgrass cv. Greenwich and the colonial bentgrass cv. Tiger, was lowest for 15-week-old plants compared with 9-, 11-, and 13-week-old plants (Fig. 3). Bentgrass cultivars, with the exception of 9week-old plants, became more resistant to T. incarnata as they aged. In 13- and 15week-old plants, disease severity of colonial bentgrass cv. Tiger was similar to that of creeping bentgrass cultivars, but was lower than that of velvet bentgrass cv. Greenwich. Interestingly, 9-week-old plants of all creeping bentgrass cultivars tested, as well as the velvet bentgrass cv. Greenwich, showed much less disease severity in all three isolates than 11-weekold plants, but a similar trend was not observed in the colonial bentgrass cv. Tiger.

Disease severity among the three bentgrass species showed highly significant effects of ploidy contrast between tetraploid creeping and colonial bentgrasses and diploid velvet bentgrass $(P<$ 0.0001 ) (Tables 3 and 4). Disease severity in creeping and colonial bentgrass cultivars was significantly less than velvet bentgrass cultivars for all isolates tested, whereas creeping and colonial bentgrass cultivars were not statistically different. The cvs. L-

Table 3. Analysis of variance for gray snow mold severity on nine cultivars of three bentgrass species inoculated with five isolates of Typhula incarnata in the growth chamber

\begin{tabular}{lrcrc}
\hline Source of variation & df & Mean square & $\boldsymbol{F}$ value & \multicolumn{1}{c}{$\boldsymbol{P}$} \\
\hline Replication & 4 & 34.4 & 0.54 & 0.7098 \\
Ploidy $^{\mathrm{a}}$ & 1 & $2,343.8$ & 36.54 & $<0.0001$ \\
Genome (ploidy) & 1 & 23.5 & 0.37 & 0.5459 \\
Cultivar (ploidy $\times$ genome) & 6 & 353.0 & 5.50 & $<0.0001$ \\
Isolate & 4 & $10,231.3$ & 159.51 & $<0.0001$ \\
Isolate $\times$ ploidy & 4 & 67.5 & 1.05 & 0.3813 \\
Isolate $\times$ genome (ploidy) & 4 & 204.4 & 3.19 & 0.0143 \\
Isolate $\times$ cultivar (ploidy $\times$ genome) & 24 & 96.9 & 1.51 & 0.0653 \\
Error & 220 & 64.1 & $\ldots$ & $\ldots$ \\
\hline
\end{tabular}

${ }^{a}$ Creeping and colonial bentgrass are allotetraploid with $\mathrm{A}_{2} \mathrm{~A}_{2} \mathrm{~A}_{3} \mathrm{~A}_{3}$ and $\mathrm{A}_{1} \mathrm{~A}_{1} \mathrm{~A}_{2} \mathrm{~A}_{2}$ genomes, respectively. Velvet bentgrass, with $A_{1} A_{1}$ genome, is diploid (20).
93 (creeping bentgrass), Bardot (colonial bentgrass), and Vesper (velvet bentgrass) were less susceptible than the other two cultivars of each species tested in this study. A significant isolate effect $(P<$ 0.0001 ) was observed (Tables 3 and 4). $T$. incarnata isolates 11 and 19 were found to be much more aggressive to most cultivars tested than the other isolates (Table 4).

No significant differences $(P<0.3027)$ were observed between the two runs of the comparison of 15 isolates for aggressiveness on two creeping bentgrass cultivars (data not presented); therefore, mean disease values of the runs were used for statistical analysis. All 15 isolates were pathogenic on the cultivars, ranging from 10.8 to $33.3 \%$ diseased area (Table 5; Fig. 4). Significant differences $(P<0.0001)$ in aggressiveness among isolates within state were detected. Isolates 3 (Michigan), 7 (Minnesota), 15, and 17 (Wisconsin) were capable of causing severe disease. On the other hand, isolates 5 (Michigan), 9 (Minnesota), and 14 (Wisconsin) were less aggressive. However, there were no significant differences among the three states in isolate aggressiveness.

\section{DISCUSSION}

The response of the cultivars to $T$. incarnata isolates was quantitatively controlled as observed in a previous study (34). Disease symptoms developed more slowly on less susceptible cultivars than susceptible ones tested. This same phenomenon also has been recognized in a wheat-snow mold pathosystem $(3,13)$ and in a bentgrass $-T$. ishikariensis pathosystem (7).

Inoculum concentration significantly affected gray snow mold development on bentgrass cultivars. Generally, symptom development increased significantly as inoculum concentration increased. Disease severity was lower on L-93 at most inocu-

Table 4. Disease severity of nine bentgrass cultivars of three bentgrass species inoculated with five isolates of Typhula incarnata in the growth chamber

\begin{tabular}{|c|c|c|c|c|c|c|c|}
\hline \multirow[b]{2}{*}{ Species, cultivar } & \multicolumn{5}{|c|}{ Isolate no. } & \multirow[b]{2}{*}{ Mean } & \multirow[b]{2}{*}{$\mathbf{L S D}_{\mathbf{0 . 0 5}}{ }^{\mathrm{a}}$} \\
\hline & 11 & 12 & 13 & 16 & 19 & & \\
\hline \multicolumn{8}{|l|}{ Creeping bentgrass } \\
\hline L-93 & 53.3 & 15.8 & 15.0 & 22.5 & 30.8 & 27.5 & 8.9 \\
\hline Penncross & 60.0 & 25.0 & 20.8 & 22.5 & 39.2 & 33.5 & 4.6 \\
\hline Providence & 56.7 & 15.8 & 15.8 & 27.5 & 38.3 & 30.8 & 6.4 \\
\hline Mean & 56.7 & 18.9 & 17.2 & 24.2 & 36.1 & 30.6 & $\ldots$ \\
\hline $\mathrm{LSD}_{0.05}$ & 17.6 & 3.8 & 4.4 & 8.0 & 3.8 & $\ldots$ & $\ldots$ \\
\hline \multicolumn{8}{|l|}{ Colonial bentgrass } \\
\hline Bardot & 39.2 & 23.3 & 15.8 & 20.8 & 35.0 & 26.8 & 9.5 \\
\hline SR 7100 & 59.2 & 26.7 & 29.2 & 23.3 & 35.8 & 34.8 & 8.9 \\
\hline Tiger & 52.5 & 18.3 & 25.0 & 29.2 & 36.7 & 32.3 & 10.8 \\
\hline Mean & 50.3 & 22.8 & 23.3 & 24.4 & 35.8 & 31.3 & $\ldots$ \\
\hline $\mathrm{LSD}_{0.05}$ & 16.5 & 9.2 & 8.3 & 3.8 & 4.6 & $\ldots$ & $\ldots$ \\
\hline Mean (creeping + colonial) & 53.5 & 20.9 & 20.3 & 24.3 & 36.0 & 31.0 & $\ldots$ \\
\hline \multicolumn{8}{|l|}{ Velvet bentgrass } \\
\hline Barvaria & 61.7 & 31.7 & 29.2 & 36.7 & 42.5 & 40.4 & 9.5 \\
\hline Greenwich & 62.5 & 25.8 & 30.8 & 32.5 & 34.2 & 37.2 & 5.2 \\
\hline Vesper & 57.5 & 27.5 & 16.7 & 30.0 & 39.2 & 34.2 & 10.9 \\
\hline Mean & 60.6 & 28.3 & 25.6 & 33.1 & 38.6 & 37.2 & $\ldots$ \\
\hline $\mathrm{LSD}_{0.05}$ & 15.6 & 11.8 & 4.4 & 5.0 & 1.9 & $\ldots$ & $\ldots$ \\
\hline
\end{tabular}

${ }^{\mathrm{a}} \mathrm{LSD}_{0.05}=$ least significant difference. 
lum concentrations than on other cultivars. However, difference in the disease severity among cultivars was not significant in the highest concentration $(0.4 \mathrm{~g} / \mathrm{ml} \mathrm{mfw})$. This suggests that, under the higher disease pressure, differences in cultivar susceptibility may be masked by overwhelming inoculum concentration. Therefore, for screening methods of bentgrass cultivars or germplasms for resistance to gray snow mold under controlled conditions, an inoculum concentration of $0.3 \mathrm{~g} / \mathrm{ml} \mathrm{mfw}$ is suggested for measurable separation among cultivars to be evaluated. However, further studies under field conditions should be required to verify the response of bentgrass plants to various inoculum concentrations.

As plants grew older, the three bentgrass species became less susceptible to $T$. incarnata (Table 2; Fig. 3). This result implies that expression of age-related resistance to $T$. incarnata may occur in bentgrass plants, as recognized in the interaction of other snow mold pathogens with grasses $(1,7,11,12,26)$. Nakajima and Abe (26) reported that older, hardened winter wheat plants express higher resistance to snow mold than young plants similarly hardened under controlled conditions. This has been reported to be associated with the rapid accumulation of high levels of carbohydrates (3) during hardening and slower metabolization of the carbohydrates $(21,37)$ in older plants. In the present study, however, disease severity of 9-week-old plants of bentgrass cultivars, with the exception of Tiger, was less than that of 11-week-old ones. A possible interpretation for this result may be the slower infection caused by fewer tillers in pots of 9-week-old plants than in pots of older plants.

The fact that disease severity of L-93, a less susceptible cultivar, indicated dramatically decreased susceptibility at 13 weeks, whereas Greenwich showed a significant decrease in susceptibility at 15 weeks, may be associated with earlier and higher accumulation of physiologically active substances involved with snow mold resistance in the former cultivar (14). At 15 weeks, susceptibility to gray snow mold was approximately equivalent in all bentgrass cultivars tested, suggesting that cultivars had acquired similar maximum levels of resistance to $T$. incarnata. Therefore, testing plants at more than 15 weeks might express a different level of resistance to gray snow mold under controlled conditions. Although significant interactions between isolate and plant age within cultivar were observed in this experiment, we could not determine the cause of the interactions. The fact that variation of disease severity among isolates within each cultivar, which was much higher on younger plants ( 9 and 11 weeks old) compared with older plants (13 and 15 weeks old) may indicate that infection and disease severity was critically affected by infection time and disease progress, because plants in early ages have fewer tillers and are more susceptible responses to the pathogen (7).

The creeping and colonial bentgrass cultivars tested in this study were significantly less susceptible to $T$. incarnata than velvet bentgrass cultivars (Tables 3 and 4). No significant difference was found between creeping and colonial bentgrasses. These results differ from the report by Gould et al. (15), where field resistance of the three species were in the order of creeping $>$ velvet $>$ colonial bentgrass. This discrepancy may be caused by significant genotypic variations, such as those reported by Wang et al. (34), where differences in the observed among 360 creeping bentgrass clones collected from old golf courses in Wisconsin. In addition, greenhouse tests may not be reliable predictors of field performance because field conditions such as host nutrient status, aggressiveness of isolate, and environmental conditions can affect bentgrass susceptibility $(1,4,21)$. According to National Turfgrass Evaluarelative susceptibility to $T$. incarnata were

tion Program data, under field conditions, disease severity within velvet bentgrass cultivars was more variable than severity within both creeping and colonial bentgrass cultivars.

Nevertheless, our result suggests that ploidy level contrast (tetraploid versus diploid) explained most of the variation among the species. It is possible that the resistance genes to gray snow mold may be conferred in the common subgenome $\left(\mathrm{A}_{2} \mathrm{~A}_{2}\right)$ of creeping $\left(\mathrm{A}_{2} \mathrm{~A}_{2} \mathrm{~A}_{3} \mathrm{~A}_{3}\right)$ and colonial $\left(\mathrm{A}_{1} \mathrm{~A}_{1} \mathrm{~A}_{2} \mathrm{~A}_{2}\right)$ bentgrasses. Velvet bentgrass, which is diploid, lacks the $\mathrm{A}_{2} \mathrm{~A}_{2}$ subgenome (20). Further research would determine whether the effect is due to polyploidy itself or whether the $\mathrm{A}_{2} \mathrm{~A}_{2}$ subgenome is responsible for increased resistance.

Significant differences in aggressiveness among isolates within each state were observed (Table 5; Fig. 4). Interestingly, there were no significant differences in aggressiveness between isolates collected from the three states. The significant variation among the isolates might be caused by high rates of outcrossing and sexual re-

Table 5. Analysis of variance for gray snow mold severity on two cultivars of creeping bentgrass inoculated with fifteen isolates of Typhula incarnata from Michigan, Minnesota, and Wisconsin in the growth chamber

\begin{tabular}{lrccc}
\hline Source of variation & df & Mean square & $\boldsymbol{F}$ value & $\boldsymbol{P}$ \\
\hline Replication & 4 & 24.7 & 0.66 & 0.6215 \\
Isolate (location) & 12 & 289.4 & 7.71 & $<0.0001$ \\
Location & 2 & 34.2 & 0.91 & 0.4040 \\
Cultivar & 1 & 911.3 & 24.29 & $<0.0001$ \\
Cultivar $\times$ isolate (location) & 14 & 236.0 & 6.29 & $<0.0001$ \\
Error & 145 & 37.5 & $\ldots$ & $\ldots$ \\
\hline
\end{tabular}

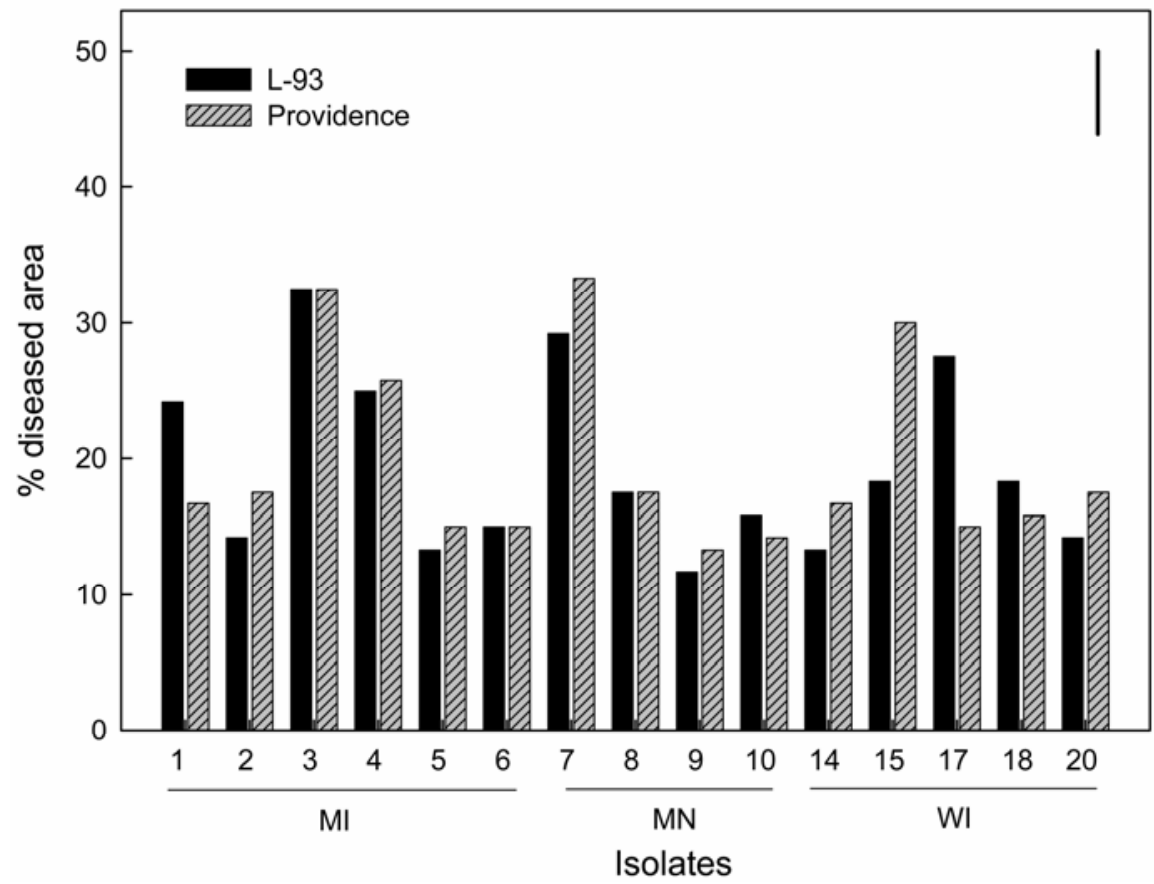

Fig. 4. Disease severity of two creeping bentgrass cultivars inoculated with 15 isolates of Typhula incarnata obtained from Michigan (MI), Minnesota (MN), and Wisconsin (WI) in the growth chamber. Disease severity was based on percent area diseased. Vertical lines represent the least significant differences $(P<0.05)$. 
combination $(5,33)$. In particular, weather conditions around the northern Great Lakes during fall such as moisture, temperature, and wind may give the fungus a favorable environment for production and dispersal of sexual structures called basidiocarps bearing basidiospores. Basidiocarps of T. incarnata and T. ishikariensis were observed at a driving range of Gateway Golf Club, Land O' Lakes, WI in the first week of November 2004 and last week of October 2005 (19).

Further, Vergara et al. (33) reported that no correlation was found between geographic distance and DNA marker-derived genetic distance of isolates collected from the three states. Even if sampling sites within each state or among three states show broad geographical distribution and long distance (Fig. 1), the low levels of variation in aggressiveness among the three states may be due to human interference by way of transport, equipment contaminated by their long survival period (10), and similar selection pressures from fungicide applications, the same source of infected sod (30), and similarity of host species or cultivars of turfgrass around the northern Great Lakes regions (33). In addition, an advantage of T. incarnata as a good saprophyte may allow the fungus to occupy a broader ecological niche $(22,23)$.

Significant interactions detected between cultivar and isolate in our studies can be interpreted carefully as differential or race-specific, because the numbers of fungal isolates and bentgrass cultivars were not sufficient for such a conclusion. We suggest that further investigation using more samples and incorporating several methods of disease assessment are warranted in order to differentiate bentgrass and T. incarnata interactions. A cultivar effect $(P<0.0001)$ observed in this experiment might be explained by the genetic variation of isolates as well as cultivar interactions.

Overall, under controlled conditions, appropriate inoculum concentration of $T$. incarnata and the use of bentgrass plants at the proper age are very important for evaluation of the resistance capabilities of bentgrass cultivars or clones to $T$. incarnata. The information on quantitative variation in susceptibility of three bentgrass species to T. incarnata and in isolate aggressiveness also may be beneficial to bentgrass breeders so that a few virulent isolates can be utilized to screen bentgrass cultivars resistant to $T$. incarnata, saving both valuable space and time. However, further field evaluation is required to confirm the current results on variation in susceptibility of cultivars of bentgrasses and in aggressiveness of $T$. incarnata isolates with different geographic origins.
ACKNOWLEDGMENTS

We thank Z. Atallah, P. Rogers, and S. Abler for their valuable comments and critical review.

\section{LITERATURE CITED}

1. Årsvoll, K. 1977. Effect of hardening, plant age, and development in Phleum pratense and Festuca pratensis on resistance to snow mold fungi. Meld. Sci. Rep. Agric. Univ. Norway 56:1-13.

2. Brilman, L. A. 2003. Velvet bentgrass (Agrostis canina L.). Pages 201-205 in: Turfgrass Biology, Genetics, and Breeding. M. D. Casler and R. R. Duncan, eds. John Wiley \& Sons, Hoboken, NJ.

3. Bruehl, G. W. 1982. Developing wheat resistant to snow mold in Washington State. Plant Dis. 66:1090-1095.

4. Bruehl, G. W., and Cunfer, B. M. 1971. Physiologic and environmental factors that affect the severity of snow mold of wheat. Phytopathology 61:792-799.

5. Bruehl, G. W., and Machtmes, R. 1978. Incompatibility alleles of Typhula incarnata. Phytopathology 68:1311-1313.

6. Burpee, L. L., Mueller, A. E., and Hannusch, D. J. 1990. Control of Typhula blight and pink snow mold of creeping bentgrass and residual suppression of dollar spot by triadimefon and propiconazole. Plant Dis. 74:687-689.

7. Chang, S. W., Chang, T. H., Tredway, L., and Jung, G. 2006a. Aggressiveness of Typhula ishikariensis to cultivars of bentgrass species (Agrostis spp.) under controlled environment conditions. Plant Dis. 90:951-956.

8. Chang, S. W., and Hwang, B. K. 2003. Effects of plant age, leaf position, inoculum density, and wetness period on Bipolaris coicis infection in adlays of differing resistance. Plant Dis. 87:821-826

9. Chang, S. W., Scheef, E., Abler, R. A. B., Clayton, M. K., Thomson, P., Johnson, P., and Jung, G. 2006b. Distribution of Typhula species and $T$. ishikariensis varieties in Wisconsin, Utah, Michigan and Minnesota states. Phytopathology 96:926-933.

10. Coley-Smith, J. R., and Cooke, R. C. 1971. Survival and germination of fungal sclerotia. Annu. Rev. Phytopathol. 9:65-92.

11. Gaudet, D. A. 1994. Progress toward understanding interaction between cold hardening and snow mold resistance and development of resistance cultivars. Can. J. Plant Pathol. 16:241-246.

12. Gaudet, D. A., and Chen, T. H. H. 1987. Effects of hardening and plant age on development of resistance to cottony snow mold $(\mathrm{Co}$ prinus psychromorbidus) in winter wheat under controlled conditions. Can. J. Bot. 65:1152-1156.

13. Gaudet, D. A., and Kozub, G. C. 1991. Screening winter wheat for resistance to cottony snow mold under controlled conditions. Can. Plant Sci. 71:957-965.

14. Gaudet, D. A., Laroche, A., and Yoshida, M. 1999. Low temperature wheat-fungal interactions: a carbohydrate connection. Physiol. Plant 106:437-444.

15. Gould, C. J., Goss, R. L., Law, A. G., and Ashworth, B. 1978. Disease resistance and quality of bentgrasses in Washington State. U. S. Golf Assoc. Green Sect. Record Sept/Oct, 511.

16. Hsiang, T., Matsumoto, N., and Millett, S. M. 1999. Biology and management of Typhula snow molds of turfgrass. Plant Dis. 86:788798.

17. Iriki, N. 1991. Minimum number of replications to estimate snow mold resistance of wheat under field condition. Bull. Hokkaido Natl. Agric. Exp. Stn. Rep. 156:91-162.
18. Jackson, N., and Fenstermacher, J. M. 1969. Typhula blight; its cause, epidemiology and control. J. Sports Turf Res. Inst. 45:67-73.

19. Jo, Y., and Jung, G. 2006. Protecting turfgrass from Typhula blight. Golfdom. Feb:62-67.

20. Jones, K. 1956. Species differentiation in Agrostis. I. Cytological relationships in Agrostis canina L. J. Genet. 54:370-376.

21. Kiyomoto, R. K., and Bruehl, G. W. 1977. Carbohydrate accumulation and deletion by winter cereals differing in resistance to $T y$ phula idahoensis. Phytopathology 67:206-211.

22. Matsumoto, N. 1994. Ecological adaptations of low temperature plant pathogenic fungi to diverse winter climates. Can. J. Plant Pathol. 16:237-240.

23. Matsumoto, N., and Tajimi, A. 1988. Lifehistory strategy in Typhula incarnata and $T$. ishikariensis biotypes $\mathrm{A}, \mathrm{B}$, and $\mathrm{C}$ as determined by sclerotia production. Can. J. Bot. 66:2485-2490.

24. Matsumoto, N., and Tajimi, A. 1993. Effect of cropping history on the population structure of Typhula incarnata and Typhula ishikariensis. Can. J. Bot. 71:1434-1440.

25. Nakajima, T., and Abe, J. 1990. A method for assessing resistance to the snow molds Typhula incarnata and Microdochium nivale in winter wheat incubated at the optimum growth temperature ranges of the fungi. Can. J. Bot. 68:343-346.

26. Nakajima, T., and Abe, J. 1996. Environment factors affecting expression of resistance to pink snow mold caused by Microdochium nivale in winter wheat. Can. J. Bot. 74:17831788.

27. Ruemmele, B. A. 2003. Agrostis capillaries (Agrostis tenuis Sibth.) colonial bentgrass. Pages 187-200 in: Turfgrass Biology, Tenetics, and Breeding. M. D. Casler and R. R. Duncan, eds. John Wiley \& Sons, Hoboken, NJ

28. Schneider, E. F., and Seaman, W. L. 1988 Saprophytic behavior of three Typhula species on winter wheat substrates. Can. J. Plant Pathol. 10:289-296.

29. Smith, J. D. 1980. Snow mold resistance in turf grasses and the need for regional testing. Pages 275-282 in: Proc. 3rd Int. Turfgrass Res. Conf. 9th, J. B. Beard, ed. Am. Soc. Agron. Crop Sci. Soc. Am., Soil Sci. Soc. Am., Int. Turfgrass Soc.

30. Smith, J. D., Jackson, N., and Woolhouse, A. R. 1989. Fungal Diseases of Amenity Turfgrasses, 3rd ed. E. and F. Spon, London.

31. Steel, R. G. D., Torrie, J. H., and Dickey, D. A. 1996. Principles and Procedures of Statistics: A Biometrical Approach, 3rd ed. McGrawHill, New York.

32. Vargas, J. M., Jr. 1994. Management of Turfgrass Diseases. CRC Press, Boca Raton, FL.

33. Vergara, G. V., Bughrara, S. S., and Jung, G. 2004. Genetic variability of grey snow mold (Typhula incarnata). Mycol. Res. 108:12831290.

34. Wang, J., Casler, M. D., Stier, J. C., Gregos, J. S. and Millet, S. M. 2005. Genotypic variations for snow mold reaction among creeping bentgrass clones. Crop Sci. 45:399-406.

35. Warnke, S. 2003. Creeping bentgrass (Agrostis stolonifera L.) Pages 175-185 in: Turfgrass Biology, Genetics, and Breeding. M. D. Casler and R. R. Duncan, eds. John Wiley \& Sons, Hoboken, NJ.

36. Worf, G. L. 1988. Evaluating snow mold control. Golf Course Manage. 58:70-80.

37. Yoshida, M., Abe, J., Moriyama, M., Shimokawa, S., and Nakamura, Y. 1997. Seasonal changes in the physical state of crown water associated with freezing tolerance in winter wheat. Physiol. Plant 99:363-370. 